Информационное пространство. Медиадискурс

信息领域与媒体话语

Information Space. Media Discourse

YAK 070:81(470+510)

DOI: 10.17150/2587-7445.2019.3(4).53-65

Культурная память России и Китая в ментальном ландшафте СМи

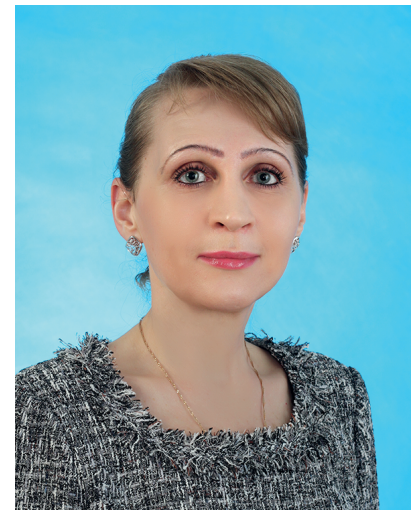

\section{И.В. Ерофеева}

Забайкальский государственный университет,

Чита, Россия

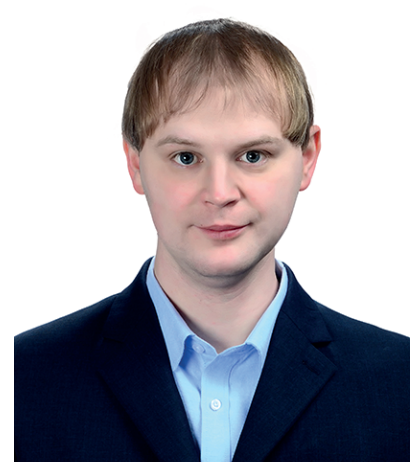

\section{A.в. Муравьёв}

Хулуньбуирский институт, Хайлар, КНР

Аата поступления:

30.09.2019

Аата принятия к печати:

16.12.2019

Аата онлайн-размещения: 28.12.2019
Аннотация. Представлен мингвокультурологический анализ ключевых концептов национального мировидения в российских и китайских СМИ. ПреАложено обоснование концептуальной картины мира, объективированной в медиадискурсе. Концепты, как когнитивно-языковые структуры, подАерживаются фоновыми знаниями алресанта и алресата, задействуют смыслы прототекста, стимулируют адекватную интерпретацию медиатекста и обеспечивают результативность его возАействия на когнитивные, эмоциональные и поведенческий уровни восприятия потребителя. Пространство подобного текста СМИ образует ментальный мандшафт, который есть совокупность ценностей, отражающих спектр жизнедеятельности мюАей определённой территории и транслирующихся во времени в парадигме "прошлое - настоящее - будущее». На основе исследований в области когнитивной и психо - лингвистики, журналистики, социальной философии утверждается, что новыми технологиями медиа, текстовыми и форматными, управляет комективная культурная память. Эмпирическую базу исслеАования составили более 500 текстов российских и китайских СМИ. Культурный ландшафт медиадискурса представлен текстами, в которых встроены ядерные концепты национальной картины мира России и Китая: комлективизм (соборность), патриотизм. В статье Аана характеристика особенностям репрезентации Аанных концептов во взаимосвязи с процессом объективации Аоминирующих ценностей культуры Китая и России. Интенсивная репрезентация концептов в массмедиа обеспечивает необходимую национальную идентификацию в российском и китайском социуме, позволяет реализовывать культурно-наследственную функцию СМИ и защищать исконные традиции общества, транслировать идеалы и культурное наследие предыдущих поколений. 
Ключевые слова. СМИ, Россия и Китай, культурная память, концепт, языковая личность медиатекста, национальная илентичность, национальная картина мира, ментальный мандшафт медиадискурса, репрезентация.

\section{俄罗斯和中国在媒体心理景观中的文化记忆}

\section{Erofeeva I.V.}

后贝加尔国立大学

赤塔，俄罗斯联邦

\section{Muravyov A.V.}

呼伦贝尔大学，海拉尔， 中华人民共和国

结稿日期：2019年9月30日

出版日期：2019年12月16日

网上出版日期：2019年12月28日
摘要。介绍了对俄罗斯和中国媒体中民族世界观主要概 念的语言文化分析。提出了媒体讨论中客观的世界概念图 的理由。作为认知-语言结构的概念，得到了传达者和接 受者的背景知识的支持，使用原型文本的含义，激发对媒 体文本的充分解释，并确保其对消费者感知的认知，情感 和行为水平的影响。此类媒体文本的空间形成了一种心理 景观，它是一组反映特定地区人民生活谱系的价值，并以 “过去-现在-未来” 的形式随时间传播。基于认知和心理 语言学，新闻学，社会哲学领域的研究，有人认为新的媒 体技术，文本和格式受集体文化记忆的控制。该研究的经 验基础是500多种俄罗斯和中国媒体的著作。媒体话语的文 化景观由嵌入俄罗斯和中国世界国家景象的核概念的文本 代表：集体主义 (共谋)，爱国主义。本文结合中国和俄 罗斯主要文化价值观的客观化过程，描述了这些概念的表 述特征。在大众媒体中对概念进行集中表示，可以在俄罗 斯和中国社会中获得必要的民族认同，可以实现媒体的文 化继承的功能，并保护社会的原始传统，传播前几代人的 思想和文化遗产。

关键词。媒体，俄罗斯和中国，文化记忆，概念，媒体讨 论的语言人格，国家认同，世界图景的民族性，媒体心理景 观，代表制。

\section{Cultural Memory of Russia and China in Mental Landscape of Mass Media}

\section{Erofeeva I.V.}

Zabaikalye State University

Chita, Russia

\section{Muravyov A.V.}

Hulunbuir Institute,

Hailar, China

Received: September 302019

Accepted: December 162019

Available online: December 282019
Abstract. The article presents a linguoculturological analysis of key concepts of national vision in the Russian and Chinese mass media. It offers substantiation of a conceptual view of the world objectified in a media discourse. The concepts, as cognitive-linguistic structures, are supported by the background knowledge of the addressee and the addresser, involve the meanings of the proto-text, stimulate an adequate interpretation of the media text and ensure the effectiveness of its impact on the cognitive, emotional and behavioral levels of consumer's perception. The space of such a media text forms a mental landscape, which is a set of values that reflect the spectrum of people's life on a certain territory and that are broadcast over time in the paradigm of "past - present - future". Based on research in the field of 
cognitive linguistics and psycholinguistics, journalism, social philosophy, it is argued that the new media technologies, textual and formatted ones are controlled by a collective cultural memory. The empirical base of the study was more than 500 texts of Russian and Chinese mass media. The cultural landscape of the media discourse is represented by texts in which the nuclear concepts of the national view of the world in Russia and China are embedded: collectivism (collegiality), patriotism. The article describes the features of these concepts' representation in conjunction with the process of objectification of the dominant cultural values of China and Russia. An intensive representation of the concepts in mass media provides necessary national identification in Russian and Chinese societies, allows to implement the cultural hereditary function of the media and to protect the primordial traditions of the society, to transmit the ideals and cultural heritage of the previous generations.

Key words. Mass media, Russia and China, cultural memory, concept, linguistic personality of media text, national identity, national view of the world. mental landscape of media discourse, representation.

Введение. Современную политику сложно представить без объединений и союзов, гарантирУющих поААерЖку в слоЖной экономической, политической и военной ситуации. В 2001 г. Аокументально был обозначен альянс России и Китая, президент РФ Владимир Путин и преАсеАатель КНР Цзян Цзэминь поАписали программный Аокумент, опреАеляющий развитие российско-китайских отношений в новом мире, - "Аоговор о добрососеАстве, Аружбе и сотрудничестве".

Но и Ао этой знаменательной даты многоаспектные взаимодействия России с Китаем были достаточно плотные, как на правительственном уровне, так и в сфере общечеловеческих отношений меАу гражАанами наших стран. В рамках договора мы официально были объявлены союзниками и еАиномышменниками, ориентированными на Аолгосрочное стратегическое партнёрство. Стали частыми встречи президентов, проводятся совместные военные учения, активно реализовываются экономические проекты, зак^ючаются газовые контракты, обсуждаются
Аоговорённости в сфере космической промышленности, китайские компании сыграли важнейшую роль в строительстве крымского энергомоста.

Некоторые европейские политики настороженно наблюдают за начавшемся объеАинением Авух крупнейших стран, тем не менее, образовавшийся альянс непосредственно соответствует национальным приоритетам наших стран. K сожалению, глобализация способствует нивелированию национальных границ и государств, в эпоху информационной, социальной, экономической интеграции всё сложнее сохранить свой исконный культурный коА, свои самобытные формы трансляции национальных смыслов. В межкультурном Аиалоге Китая и России есть свои не только политические, но и духовные интересы.

Культурная память в сфере массмедиа. Методология вопроса.

ОчевиАно, что сохранение самобытности той или иной страны неразрывно связано с культурной преемственностью и тиражирова- 
нием исконных образцов мировосприятия. Закрепление Аанных конструктов в пространстве массмедиа обусловлено особенностями речемыслительной деятельности человека с помощью языка. Язык, точнее его концептуальное содержание, отражает национальную философию социума. В концептах и национальных стереотипах фиксируется богатый опыт многочисленных поколений и закреплены основные коды культуры. Лексика, синтаксис и Аругие составляющие языка - лишь вспомогательный инструмент Аля объективации сознания человека.

В рамках современной когнитивной мингвистики языковая мичность автора меАиатекста - это мичность, выраженная в языке текста и через язык. Создатель медиапроизведения, будучи субъектом определённой национальной общности, олицетворяет языковую мичность конкретной культуры и представляет собой совокупность способностей и характеристик человека, обуславливающих создание и восприятие им речевых произведений - текстов [1-3]. Автор, воспринимая и обрабатывая фактуру окружающего мира, апемлирует еАиными Аля него и потребителя фоновыми знаниями, он нацелен на интерпретацию Аействительности, которая осуществляется в рамках его национальной картины мира. ОчевиАно, что только сквозь призму инАивиАуальной памяти мы можем "взглянуть на коммективную память" [4, с. 31].

^ингвокультурный шаблон восприятия и отражения мира в пространстве текста связан с апперцепцией - внутренней готовностью автора и потребителя воспринимать и интерпретировать какой-либо объект или эпизод определённым образом, что, в свою очереАь, способствует сохранению социокультурной стабильности. Репрезентация национальных ценностей в СМИ посредством концептов позволяет защищать траАиции, взгляАЫ, убежАения и ценности определённой страны, она созАаёт плоАотворную почву А^я илентификации - конструирования и сохранения важного Аля нации образа "Мы". Традиционный и привычный канон мысли, восприятия и повеАения есть конструктив- ная косность и ригиАность картины мира, крайне необходимая Аля выживания социума и самих массмедиа.

В национальной картине мира смысловым стержнем её организации выступает концепт, который замещает нам в процессе мыслительной деятельности неопределённое множество преАметов оАного и того же смыс^ового блока. В своей статье мы придерживаемся ^ингвокультурного направления, изучающего специфику национальной концептосферы и рассматривающего культуру как совокупность концептов и отношения межау ними. В рамках Аанного подхода Ю. Степанов называет концепт "основной ячейкой культуры в ментальном мире человека" [5, с. 43]. В своих многочисленных исследованиях мы изучаем языковое наполнение концептов в медиатексте как элементов отечественной культуры автора в их тесной взаимосвязи с национальными ценностями страны [6].

Концепт представляет собой некую символическую смысловую схему, аккумулирующую устойчивые преАставления, эмоции, паттерны поведения социума относительно важных категорий человеческого бытия. С.Г. Воркачёв именует концепт "единицей комективного знания/ сознания" [7], Е.С. Кубрякова - "оперативной содержательной еАиницей памяти", так как концепт концентрирует общезначимые Аля мингвокультурной общности признаки и соответствующий народный опыт [8, с. 275]. Концепты отражают культурное ялро социума, Аемонстрируют сущность его национального менталитета, раскрывают особенности способов общения и деятельности людей. С точки зрения В.В. Колесова, концепты преАставляют собой опорные сети коренных понятий национальной культуры и существуют вне времени и пространства, познаются интуитивно и воспринимаются носителями культуры одинаково, но с разной силой и энергией [9, с. 25].

Концепт по своей природе - аксиологичен, он репрезентирует Ауховно-нравственные ценности, смысл которых знаково оформляется в концептуальном поле языка. Концепт есть своеобразный сгусток культуры в сознании автора медиатекста, 
посреАством концепта он рефмексирует и приобщается к культуре, а изучение концептуализированной сферы массмедиа позволяет моделировать национальную и аксиологическую картину мира представителя определённого социума.

Сконструированные с использованием национальных представлений медиатексты образуют культурный ландшафт массмедиа, имманентно ориентированный в прошлое, отражающий реальность сегодняшнего дня и создающий ценностный фундамент Аля буАущего. Пространство подобного текста есть совокупность необходимых ценностей, которая транслируется во времени и определяет спектр нынешней и будущей жизнедеятельности людей определённой территории.

Культурный ландшафт массмеАиа воспроизводит знаковые системы конкретной культуры. Это явление, обусловленное географическим пространством и межащее в срезе семиосферы социума, оно Аемонстрирует возможности, потенциал и инструментарий культурной памяти человека. Термин "культурная память" принадлежит Яну Ассману, который в монографии «Культурная память. Письмо, память о прошлом и политическая идентичность в высоких культурах Аревности" подчёркивает приклаАную значимость проблем памяти и воспоминаний [10]. ВслеА за известным культурологом профессор В. Ф. Олешко понимает "культурную память" как особую форму не только актуализации, но и трансляции при посреАстве массмедиа различных культурных смыслов. Ведь Аанный виА памяти - это в первую очереАь “порожАение несовременности" и "обретение/ воскрешение смысла" [11]

В современном мире глобализации продвижение моделей национального мировидения первостепенно. Миру и планетарной цивилизации мы интересны лишь в той мере, в какой сохранияи свою илентичность. Сохранность самого государства в условиях информационно-психологических войн XXI века непосреАственно зависит от тотальной поддержки национальных приоритетов: «значимой Аля обеспечения многих социальных функций государства, в том числе и построение надежной социальной ISSN 2587-7445 безопасности, является задача формирования массовой индентичности" [12, с. 162; 13].

В нашей статье поставлена цель - Аать лингвокультурологическую характеристику ялерным концептуальным смыслам российской и китайской культуры, репрезентированным в тексте СМИ - концептам Комективизм (Соборность), Патриотизм. Эмпирическую базу исследования составили более 500 текстов российских и китайских СМИ.

Россия и Китай как медиапространство общих ценностей

С.Г. Тер-Минасова справедливо замечает, что "только выйАя за рамки своей культуры, то есть, столкнувшись с иным мировоззрением, можно понять специфику своего общественного сознания, увидеть различие или конфликт культур" [14; с. 34]. Как правило, естественное ощущение себя и своего национального лика осуществляется в парадигме "Своё-Чужое", в режиме столкновения совпадений и противоречий культурных констант. Увидеть Свой мир возможно ^ишь через призму осознания и мицезрение Аругого.

В культурном поле ^юбой страны существуют ялерные концепты мировидения, которые позволяют преАставителям разных национальностей не просто говорить об оАном, но чувствовать и видеть разноликую палитру красок, аккумулированную в концептуализированной сфере, переживать схожую глубину и сложность Ауховно-бытийных смыслов человека.

По мнению польского мингвиста А. Вежбицкой, языковые и культурные системы в огромной степени отличаются Аруг от Аруга, но существуют семантические и лексические универсалии, указывающие на общий понятийный базис, на котором основывается человеческий язык, мышление и культура" $[15$, с. 322]. Китай и Россия, на наш взгляА, имеют общие культурные столпы, сближающие наши народы и гарантирующие полноценный диалог межАу странами. Специфика Аанного исследования заключается в авторской интерпретация данного диалога сквозь призму определённого менталитета, носителем которого являются авторы статьи.

В этнопсихологии измерение культур охватывает разное количество элементов, регулирующих повеАение индивиАа в общ- 
ности. Но есть стержневые компоненты культуры, относительно которых сосуществуют Аругие ментальные конструкты. Ключевой Аоминантной является "ИнАивиАУализм / коммективизм", артикулирующие ориентацию социума мибо на индивидуальные, либо на групповые цели. Россия и Китай - культуры комективистского типа, что непосредственно обусловлено историей стран.

Россия и Китай - государства, на огромных территориях которых проживают и мирно сосуществуют разные этносы. Под названием "россияне" и "китайцы" объединено множество народов и этнических групп. На территории России славянские, балтские, финские, угорские, норманнские, тюркские этнические корни постепенно смешивались, формируя новое этнические образования. Сегодня в России проживают более 190 народов. А в Китае официально насчитывается 56 национальностей.

Исследователь менталитета культуролог Г. Гачев пишет, что в России первично целое, один за всех и все за одного - "лебединая песня России" [16, с. 223, 187], в отличии, например, от Америки, построившей свою историю на собирательности инАИвиАОВ и кУльтивирующую самостоятельность и силу оАиночек. Аингвист В. В. Колесов утвержАает, что соборность есть первая особенность русского мышления, процесс которого есть соборная дума, а не мичная Мысль инАивиАа [9, с. 295].

С золотого века русской митературы и благодаря А. С. Пушкину соборность в России воспринимается как огромный хоровоА, Авижение плечом к плечу, взявшись за руки, не на разжиме, а на притяжении и обвязывании всех всеми. В образовавшемся сплочении сила - вторична, так как слабое звено хоровода удержат остальные. Аля носителей российского менталитета соборность есть единение на основе одних и тех же ценностей, это свободное притяжение АюАей, еАинство на основе свободы выбора. Аексема "еАинство" - антонимом "разобщенности и разделения", в русском языке функционирует соответствующий синонимический ряА: КонсолиАация, СОлиАарность, сплочённость, неразрывность связей.
Инаивидуализм в России не в чести. Поговорка "Моя хата с краю" характеризует злого и равнодушного человека. В нашей стране культивируется еАинство человека и мира, которые, как уточняет В.Н. Сагатовский «не против Аруг Аруга, а вместе» [17, с. 103], самоценные и самодостаточные. Приоритет и важность интересов комлектива частотна отражена в многочисленных паремиях: "ОАной рукой и узла не завяжешь", "Вместе тесно, а врозь скучно", "ОАин в поле не воин".

Согласно проведённому контент-анализу, концепт Соборность в информационном пространстве России детализирован фреймами "свобода в еАинстве", "Ауховное роАство", "Аюбовь К Аругим", "чувство Аолга" и "общая ответственность" [6, с. 212-234]. Технологии актуализации национальных смыслов многообразны. Так, в журналистских, политических и социальных коммуникациях Аостаточно часто артикулируется лексема "вместе»: Вместе со своей страной; Вместе - мы лучше, вместе мы - сила; Вместе победили; Аавайте праздновать вместе; Вместе против рака груАи; Вместе против коррупции и Ар.

Фрейм Соборность - "Свободное еАинение" в общем тексте СМИ культивирует ценности братства и ^юбви, согласие ^юАей и симфонизм народов разных национальностей, подчёркивает еАинство человека и природы, пространственно-временную целостность в исторической судьбе страны - зависимость будущего от прошлого. Востребованные сегодня Аиалоговые конструкции меАиатекста, интерактивный контент социальных проектов и ток-шоу сближает коммуникантов: создателя контента и потребителя, объективирует целостность массовой коммуникации, конструирует еАиное Мы.

В последние годы в стране массово отмечают Аень народного еАинства, смыслы и ценности этого празАника отражены в многочисленных публикациях разных СМИ: "Мы вместе. Общность бытия. Что отмечают россияне 4 ноября (Известия.ru. 2019. 4 нояб.); «Почти 70\% россиян считают, что важно отмечать Аень народного еАинства 4 ноября. По мнению граждан, этот празАник способствует сплочению. Об этом свидетельствует Аанные Всероссийского центра изучения общественного мнения" (Российская газета. 2019. 31 окт.) 
В журналистике чрезвычайных ситуаций соборный Аух героев медиатекста позволяет справляться с природными беАствиями, техногенными катастрофами, аварийными и неоднозначными житейскими ситуациями: "Таков уж русский менталитет, что объединяет нас жесткая Арака с внешним врагом. И не важно, что еще вчера твой сосеА, может, хищно поглядывал на твою жену. Или, к примеру, получил Аолжность, на которую претендовал ты. Или... Все это меркнет, когАа на горизонте появляется враг" (Вечерняя Москва. 2018. 5 нояб.); "Помогали всем миром. <...> О готовности помочь сообщили соседние регионы. Самых тяжелых вывозили транспортная авиация и вертолеты МЧС. Откликнулись все» (НТВ. 2018. 17 окт.).

Илея коммективизма крайне востребована и в истории Поднебесной, она является неотьемлемой частью китайского менталитета, но одновременно конструкт имеет свой национальный калорит. В стране Аоминирует комективистская ориентация, и направленность на коммективизм носит социогенный характер. С Аревнейших времён в Китае интересы общества стоят выше, чем интересы отАельного гражданина. Сила коммективистского начала связана как с многочисленным населением, так и с ценностями, которые пропагандировались Аревней культурой, базисом которой являются конфуцианский морально-этический комплекс, траАиции буААизма и даосизма.

Почитаемые в этой стране Великодушие и Всепрощение в рамках ментальной китайской философии есть рассредоточение своего "Я" на Аругих, в исчерпании своего сердца во имя Аругого. В национальной картине мира Поднебесной парадигма сотрудничества трактуется Аревней концепцией еАинства через гармонию разнородного - “Хэ". Истоки Аанного мировоззрения берут своё начало в VIII-VII вв Ао н.э. В то время бытовало космогоническое преАставление о взаимодействии Авух полярных сущностей: ян - мужское и светлое, инь - женское и тёмное. Борьба противоположностей воспринималась как объективный закон существования природы, благодаря которому появились пять стихий: земля, вода, огонь, Аерево и метамл. Именно ISSN 2587-7445 благодаря взаимопорождению и взаимопреодолению разностей без Аоминанты какой либо оАной стихии возможно существование всего живого в природе [18; 19] В китайской культуре еАинство и еАинение Аоступны либо на пути равного в усилиях столкновения разностей через взаимное преодоление полярных воззрений, либо на иной основе Аоговорённости, когАа участники Аобровольно соглашаются на преАложение от правителя. В Аревнекитайских трактатах постулируется необходимость гармонического еАинства лишь в опоре соглашательских взаимоотношений внутри иерархии власти. Иерархичность взгляАов переносится и на семейные отношения: жена Аолжна быть готова погибнуть во имя мужа, муж Аолжен быть готов погибнуть ради верности правителю.

Современный Китай нацелен на сохранение уникальности своей культуры, одновременно, в том числе во внешней политике, он тяготеет к многостороннему сотрудничеству, предпочитая гармоничное еАинство разностей. Аанная парадигма особенно близка соборному ауху традиционной России.

В 2019 г. Китай с размахом отмечает 70-ю годовщину образования народной республики. Это событие широко отражено на страницах многих китайских СМИ. Так, в материале ежедневного издания "Хуаньцю шибао" (2019. 30 сент.) автор подводит итоги развития страны, комлективистский дух, также как и в русской журналистике, артикумируется за счёт мичных местоимений наш, мы, всех и лексемы "народный", тем самым Аемонстрируется объединение усилий всех жителей страны в становлении и развитии китайской экономики и государственности: "Наша страна по праву называется народной республикой. И через десять лет после того, как Китай стал второй экономикой в мире, самой обсуждаемой темой осталось народное благосостояние" (我们的国家的确 是人民共和国，我们在成为世界第二大经济 体之后的近10年里谈论最多的依然是民生); "Китайская Народная Республика - защита Аля всех китайцев. Мы - ююди разных профессий и специальностей, но все выполняем одну и ту же работу. Несколько десятилетий назаА мы с трудом могли прокормить семью, 
но вслеА за подъёмом страны, незаметно изменилось место каждого работника в системе глобализации" (中华人民共和国是所有中 国人个人命运最外部的屏障。我们是各行各 业的劳动者，一份同样的工作，在几十年前 让我们兔强养家糊口，但随着中国崛起，我 们每个劳动者在全球化体系中所处的位置悄 然变化).

ЕАиное "Мы" образует сп^очённый социум Ауховно-нравственного порядка: “Мы трудолюбивый и смелый народ, мы всегда вместе со своей страной, вся наша жизнь проходит на её прочной платформе. Наша надежда на хорошую жизнь священна, а наши старания и отАача в условиях глобализации ценятся все больше. Наша жизнь - больше не блуждание в море людей, осознанное или нет, мы все разделяем ориентацию, присущую нашей стране" (我们是勤劳勇敢的人 民，与国家在一起，我们的人生建立在了一 个坚实的平台上。我们过美好生活的愿望是 神圣的，我们的努力和付出在全球化中受到 越来越多的尊重。我们的人生不再是在茫茫 人海中的流浪，无论是否是自觉的，我们都 得以分享这个国家强有力的方向感).

Яркий метафорический пример востребованности концепта Комективизм можно увидеть в материале «Путешествие в Россию: ощущение культурного развития" китайского изАания "Байцзяхао". Автор описывает выступление членов хора как работу единого слаженного организма, слёзы вызывает патриотическая песня о родине, объединяющая исполнителей на сцене и зрителей в зале: "Хормейстер Аи Шуан настолько вАохновился всеобщей радостной атмосферой, что развернулся лицом к зрителям и будто бы стал руководить и ими. Внезапно и хор, и зрите^и запели в один голос, песня ^илась рекой, словно Ао этого все было отрепетировано. В тот момент, когАа разАались звуки китайской песни "Я и моя Родина", многие члены хора не смогли сдержать слез. Но певцы не утирали их, позволяя скатываться по щекам" (" 合唱团指挥李㸚被现场热烈的气氛所感染， 情不自禁地转身面向观众，指挥全场，台上 台下同声高歌，有的还伴着歌声翩扁朋起舞， 俨然就是事前排练好的全场秀。特别是当 《我和我的祖国》歌声响起那一刻，很多团 员都流下了热泪，可是没有一个人用手去 擦，任凭泪水尽情地流淌).
Последовательное и настойчивое отстаивание общих принципов социума создаёт благостную когнитивно-поведенческую почву Аля кристалмизации аксиологии культуры. В новостном материале издания "Жэньминь жибао" (2019. 22 окт.) подчёркивается особый путь развития Китая, который выбрал и определил сам народ: "Китай не собирается плясать поА чужую АуАКУ, он проАОлжит НеукАонно слеАовать той Аорогой и в том направлении, которое выбрал и определия дяя себя сам".

Патриотизм как “способность созерцания Ауши"

Концептуализированная сфера Комективизма неразрывно связана с концептом Патриотизм, что и Аемонстрируют преАложенные примеры российских и китайских СМИ. Смысловые акценты данных конструктов объединяют национальные картины мира России и Китая. На современном этапе развития мира в целом происходит масса событий, оказывающих влияние на патриотическое воспитание, мюбовь или нелюбовь или Ааже ненависть к своей стране, готовность или отказ служить родине. В Аанном контексте средства массовой информации выстраивают идеологию современного общества, особенно молодого поколения.

Во всем мире патриотизм в целом воспринимается как глубоко положительное чувство преданности и ^юбви к своему отечеству и своему народу, но, будучи неоднозначным проявлением человеческих ощущений, преАставляет собой сложное переплетение разных установок и ценностных ориентаций. И. А. Ильин патриотическое еАинение воспринима^ как непосредственную Аанность мировоззрения русича, ориентированного на Ауховное братство и нюбовь к своему народу. С точки зрения философа патриотизм немысмим без веры в Ауховную силу и призвание, он вырастает из способности созерцания Ауши, зижАется на воле и системе поступков, вытекающих из веры и созерцания [20].

Смысл человеческой жизни обретается через патриотизм, в принаАлежности к нации человек ощущает себя востребованным миром и причастным большой истории. ^юбовь к Отечеству вырастает из жизненно необходимого человеку инстинкта националь- 
ного самосохранения, она позволяет беречь, подАерживать и транслировать самобытность определённой культуры, способствует укреплению и жизнеспособности общества.

Человек, как правило, обеспокоен желанием понимания и чувствования родной земми. По замечанию С. Булгакова, патриотизм "не Аовольствуется инстинктивным самознанием, но ищет своего могоса" [21, с. 180]. Согласно проведённому исследованию [6], концептуализированное поле Патриотизма в общем тексте российских СМИ структурировано фреймами "патриотизм есть обязанность-Аолг", "патриотизм Аемонстрирует величие человека", "патриотизм требует дела-служения", "патриотизм - жизненно-полезен".

Композиционный рисунок многих публикаций российских СМИ репрезентирует указанные смыслы: "Родина начинается с семьи" (Аргументы и факты-Забайкалье. 2019. 1 июн.); Стройка века в Забайкамье - молодость, романтика, патриотизм" (Аргументы и факты-Забайкалья. 2014. 10 июн.); Российские школьники ценят патриотизм выше чувства личного (Комсомольская правда. 2019. 31 окт.) и Ар.

В контенте российских и китайских СМИ патриотическими идеями, как правило, наполнены медиатексты, посвящённые спортивным баталиям и историческим победам. В материалах, пробуждающих у аудитории чувство гордости за свою страну, отмечаются вековые традиции, передающиеся из поколения в поколение - благородство, преАанность делу, отвага и самоотверженность. Именно они пробуждают в читателях и зрителях чувство гордости за свою страну: "Анастасия Шамонова выиграла боксерский финал с травмой спины, а Руслан Колесников бился за золото со сломанной рукой. ЗАесь ничего не изменилось. Характер, самоотверженность и любовь к стране как были 50 или 30 лет назаА, так и остались, несмотря на все разговоры о маленьких зомби из виртуального мира" (ЦарьграА ТВ. 2018. 19 окт.); «Рушилось всё, отАелялись от России территории, но всё равно находились Аюди, которые были готовы защищать свою Родину Ао конца" (Аргументы и Факты. 2018. 25 апр.). В информационном пространстве российских ISSN 2587-7445 и китайских СМИ активно реализуется метоА илентификации - демонстрация Аля подражания положительного образца - носителя национальных чувств.

Стратегия информационной политики почти всех СМИ Китайской Народной Республики ориентирована на приобщение молодёжи к патриотическому воспитанию. В разных каналах коммуникации, от прессы Ао ТВ, наблюдается высокий процент патриотических, научно-популярных, исторических публикаций и программ. Воспитание чувства патриотизма в современной китайской молодёжной среАе является стратегической необходимостью страны. В разговоре со стуАентами престижного Пекинского университета преАседатель КНР Си Цзиньпин отметил, что главные жизненные ценности формируются в студенческом возрасте, он сравнил этот опыт с рубашкой: если первую пуговицу застегнуть неправильно, все остальное пойдёт наперекосяк. Также в своей речи на 1-й сессии Всекитайского собрания народных преАставителей (ВСНП) и Всекитайского комитета Народного политического консультативного совета Китая (BK НПКСК) 17 марта 2013 г. подчеркнул, что Аля осуществления "китайской мечты" нужно не только продолжать иАти по «пути социализма с китайской спецификой", но и необхоАимо воспевать "китайский Аух".

В этом вопросе при отсутствии частных массмедиа на территории КНР огромную помощь оказывают государственные СМИ, отвечающие за распространение информации политического и патриотического воспитания, стремящиеся поддерживать и реализовывать государственную программу. Аля китайского социума патриотические символы выступают важным компонентом повседневной жизни. В общем потоке китайских СМИ частотным выступает лексико-семантическое поле слеАующих понятий: патриотизм, патриот, национализм, родина, отечество, народ, еАинство, нация, китайская мечта и подобные им в том или ином сочетании Аруг с Аругом.

Неизменно подчёркивается сила и мощь современного Китая. Так, в материале ежеАневного издания "Хуаньцю шибао" (2019. 30 сент.) автор, акцентируя успехи страны, использует антитезу, сталкивая контрастные 
по значению слова, воспроизводящие смыс^овое пространство прошлого и настоящего: "КогАа Новый Китай только появился, его экономика была чрезвычайно слаба. На начальном этапе страну зачастую описывали как нищую и бескультурную. Самым очевидным результатом за эти 70 ^ет стали гигантские экономические достижения Нового Китая. Благодаря им КНР в одночасье стала второй экономикой мира" (新中国刚刚成立时，经济 十分刍弱，一穷二白是对新中国起步时最常 见的描述之一。新中国70年最容易辨识的是 巨大经济建设成就，这些成就使它一跃成为 世界第二大经济体。实现初步的现代化，将 人口最多的国家基本带入全面小康，大体消 灭了贫困，单凭这份成绩单就足以让新中国 在道义上高高站到时代的平均线以上).

В китайских СМИ концепт Патриотизм разворачивается за счёт когнитивных модемей "нароА", "АюАи", что делает его особенно востребованным в ^ичной жизни каждого жителя Поднебесной: «По сути стремительный рост китайской экономики преАставлял собой процесс удовлетворения стремления простых Аюдей к счастливой жизни. В первую очередь народ надо было обеспечить пищей и одежАой, этой цели УАалось Аостичь за первые годы проведения политики реформ и открытости" (从本质上说，中国经济的高 速崛起就是不断满足中国老百姓对美好生活 需求的过程。人们先是要吃饱穿暖，改革开 放的最初几年就大体做到了这些).

Актуальный Аля страны символ "китайской мечты" неизменно коррелирует с личным отношением человека к политической жизни государства, с его индивидуальным внутренним ощущением, с жизненной позицией и переживаниями, сублимированными в преАпочтение той или иной политической силы. В свою очереАь политик Аолжен Аемонстрировать интерес о народе своей страны и его благах, быть обеспокоенным укреплением силы государства: "Китайская мечта, выдвинутая Си Цзиньпином, нашла откиик в сердцах многочисленных китайцев, стала самым громким звуком в китайском обществе» (Жэньминь жибао. 2019. 30 сент.).
Заключение. Культурная память медиадискурса есть форма трансляции и актуамизации ментальных смыслов посредством концептов, это семиотическое пространство генетического знания, которое управляет когнициями, эмоциями и бытийной практикой ^юдей в рамках взаимодействия в обществе в режиме жизненно-необходимого Аля нации повторения и заучивания. Аингвокультурные структуры медиатекста призваны объединять многочисленные национальные лики современной цивилизации. В Аискурсе России и Китая концепты Комективизм и Патриотизм образуют когнитивный симбиоз ментальных сущностей, определяющих Ауховно-нравственное бытие социумов и жизнеспособность наших культур. Прагматическая цель культивирования Аанных конструктов очевиАна - сформированное посреАством медиа мировоззрение обуславливает паттерны поведения гражданина страны.

ТренА современной пропагандисткой машины США - столкнуть "Аракона" и "меАвеАя". Но изощрённые нюансы внешней политики не способны разрушить веками укоренённый ментальный коА, встроенный в культурное ялро наших стран и сближающий наши нароАы. У русской и китайской цивилизаций есть мощный повоА А^я Аальнейшего сближения, который связан не только с политическими реалиями сегоАняшнего Аня, он ЗижАется на общих культурных смыслах, в пространстве которых возможен яркий и полноценный диалог, продуктивный и полезный Аля обеих культур. В нашей парадигме "Своё-Чужое", несомненно, присутствует разный энергетический потенциал, открывающий мозаичную и национально-колоритную интерпретацию богатого мира, но также очевинно, что мы легко преоАолеваем барьер когнитивного диссонанса, неких отдельных несовпадений смыслов и духовных кодов, так как в наших национальных моделях мира существует концептуальный потенциал объединения. 


\section{Список использованной митературы}

1. Арутюнова Н.А. Язык и мир человека / Н.А. Арутюнова. - Москва : Языки русской культуры, 1998. - 896 с.

2. Карасик В.И. Языковой круг: личность, концепты, Аискурс / В.И. Карасик. - ВолгограА : Перемена, 2002. - 477 с.

3. Пименова М.В. Типология структурных элементов концептов внутреннего мира (на пример эмоциональных концептов) / М.В. Пименова // Вопросы когнитивной мингвистики. -2004 . - № 1. - С. 72-90.

4. Halbwachs M. Das kollektive Gedächtnis / M. Halbwachs. - Marburg : Fischer, 1967. $-168 \mathrm{p}$.

5. Степанов Ю.С. Константы: Словарь русской культуры / Ю.С. Степанов. - ИзА. 3-е, испр. и Аоп. - Москва : Академический проект, 2004. - 992 с.

6. Ерофеева И.В. Аксиология медиатекста в российской культуре (репрезентация ценностей в журналистике начала XXIв.) / И.В. Ерофеева. - Новосибирск : ИзА-во СО РАН, 2009. - 340 c.

7. Воркачев С.Г. Культурный концепт и значение / С.Г. Воркачев // Труды Кубанского государственного технологического университета. Серия Гуманитарные науки. - $2003-$ T. 17, № 2. - С. 268-276.

8. Кубрякова Е.С. Роль языка в познании мира / Е.С. Кубрякова. - Москва : Языки славянской культуры, 2004. - 560 с.

9. Колесов В.В. Основы концептологии / В.В. Колесов. - Санкт-Петербург : Златоуст, 2019. - 776 c.

10. Ассман Я. Культурная память. Письмо, память о прошлом и политическая идентичность в высоких культурах Аревности / Я. Ассман. - Москва : Языки славянской культуры, 2004. -368 c.

11. Олешко В.Ф. Коммуникативно-культурная память: идентификационные ресурсы современных массмедиа / В.Ф. Олешко, Е.В. Олешко. - DOI: 10.21209/1996-7853-201914-5-77-86 // Гуманитарный вектор. - 2019. - Т. 14, № 5. - С. 77-86.

12. Янгляева М.М. Роль современных массмедиа в продвижении моделей национальной самоидентификации. Зарубежный опыт (на примере телепроекта "100 векичайших британцев") / М.М. Янгляева // МедиаАльманах. - 2019. - № 1. - С. 161-169.

13. Koumandaraki A. The Evolution of Greek Identity / A. Koumandaraki // Studies in Ethnicity and Nationalism. - 2008. - Vol 2, iss. 2. - P. 39-53.

14. Тер-Минасова С.Г. Язык и межкультурная коммуникация / С.Г. Тер-Минасова. Москва : Слово, 2000. -624 с.

15. Вежбицкая А. Язык. Культура. Познание / А. Вежбицкая. - Москва : Русские словари, 1996. - 416 с.

16. Гачев Г. А. Национальные образы мира. Америка в сравнении с Россией и славянством / Г.А. Гачев. - Москва : Раритет, 1997. - 680 с.

17. Сагатовский В.Н. Русская идея: продолжим ли прерванный путь / В.Н. Сагатовский. - Санкт-Петербург : Петрополис, 1994. - 217 с.

18. Тань Аошуан Китайская картина мира: Язык, культура, ментальность / Тань Аошуан. - Москва : Рукописные памятники Аревней Руси, 2012. - 272 с.

19. Абрамова Н.А. Китайский этнос: от традиции к современности / Н.А. Абрамова. Чита : ЧитГУ, 2006. - 110 с.

20. Ильин И.А. Путь к очевидности / И.А. Ильин. - Москва : Республика, 1993. - 431 с.

21. Булгаков С.Н. Христианский социализм. Споры о судьбах России / С.Н. Булгаков. Новосибирск : Наука, 1991. - 350 с.

\section{References}

1. Arutyunova N.D. Yazyk i mir cheloveka [Language and the World of Man]. Moscow, Yazyki russkoi kul'tury Publ., 1998. 896 p. 
2. Karasik V.I. Yazykovoi krug: lichnost', kontsepty, diskurs [Language Circle: Person, Concepts, Discourse]. Volgograd, Peremena Publ., 2002. 477 p.

3. Pimenova M.V. Typology of Structural Elements of Inner World Concepts (Emotional Concepts). Voprosy kognitivnoi lingvistiki = Issues of Cognitive Linguistics, 2004, no. 1, pp. 72-90. (In Russian).

4. Halbwachs M. Das kollektive Gedächtnis. Marburg, Fischer, 1967. 168 p.

5. Stepanov Yu.S. Konstanty: slovar' russkoi kul'tury [Constants: Dictionary of Russian Culture]. $3^{\text {nd }}$ ed. Moscow, Akademicheskii proekt Publ., 2004. 992 p.

6. Erofeeva I.V. Aksiologiya mediateksta v rossiiskoi kul'ture (reprezentatsiya tsennostei $v$ zhurnalistike nachala XXI v.). [Media Text Axiology in Russian Culture (the Values Repreentation in Journalism of the Beginning of XXI Century]. Novosibirsk, Siberian Branch of the Russian Academy of Sciences Publ., 2009. 340 p.

7. Vorkachev S.G. Cultural Concept and Significance. Trudy Kubanskogo gosudarstvennogo tekhnologicheskogo universiteta. Seriya Gumanitarnye nauki $=$ Works of the Kuban State Technological University. Series of Humanitarian Sciences, 2003, vol. 17, no. 2, pp. 268276. (In Russian).

8. Kubryakova E.S. Rol' yazyka $v$ poznanii mira [The Role of Language in the World Cognition]. Moscow, Yazyki slavyanskoi kul'tury Publ., 2004. 560 p.

9. Kolesov V.V. Osnovy kontseptologii [Fundamentals of Conceptology]. Saint Petersburg, Zlatoust Publ., 2019. 776 p.

10. Assmann J. Das kulturelle Gedächtnis : Schrift, Erinnerung u. politische Identität in frühen Hochkulturen. München, Beck, Cop. 1992. 344 s. (Russ. ed.: Assmann J. Kul'turnaya pamyat'. Pis'mo, pamyat' o proshlom i politicheskaya identichnost' v vysokikh kul'turakh drevnosti. Moscow, Yazyki russkoi kul'tury Publ., 2004. 368 p.).

11. Oleshko V.F., Oleshko E.V. Communicative and Cultural Memory: Identification Resources of Modern Mass Media. Gumanitarnyi vektor $=$ Humanitarian Vector. 2019. Vol. 14, No. 5. PP. 77-86. DOI: 10.21209/1996-7853-2019-14-5-77-86. (In Russian).

12. Yanglyaeva M.M. The Role of Modern Mass Media in Promoting Models of National SelfIdentification (a Case Study of the BBC "100 Greatest Britons" Project). MediaAl'manakh = MediaAlmanah Journal, 2019, no. 1, pp. 161-169. (In Russian).

13. Koumandaraki A. The Evolution of Greek Identity. Studies in Ethnicity and Nationalism, 2008, vol 2, iss. 2, pp. 39-53.

14. Ter-Minasova S.G. Yazyki mezhkul'turnaya kommunikatsiya [Language and Intercultural Communication]. Moscow, Slovo, 2000. 624 p.

15. Vezhbitskaya A. Yazyk. Kul'tura. Poznanie [Language. Culture. Cognition]. Moscow, Russkie slovari Publ., 1996. 416 p.

16. Gachev G. D. Natsional'nye obrazy mira. Amerika v sravnenii s Rossiei i slavyanstvom [National Images of the World. America Versus Russia and Slavs]. Moscow, Raritet Publ., 1997. 680 p.

17. Sagatovskii V.N. Russkaya ideya: prodolzhim li prervannyi put' [The Russian Idea: Whether we will Continue the Interrupted Way?]. Saint Petersburg, Petropolis Publ., 1994. 217 p.

18. Tan' Aoshuan Kitaiskaya kartina mira: Yazyk, kul'tura, mental'nost' [Chinese Picture of the World: Language, Culture, Mentality]. Moscow, Rukopisnye pamyatniki Drevnei Rusi Publ., 2012. 272 p.

19. Abramova N.A. Kitaiskii etnos: ot traditsii k sovremennosti [The Chinese Ethnos: from Tradition to Modernity]. Chita State University Publ, 2006. 110 p.

20. Ilin I.A. Put' k ochevidnosti [Path to Evidence]. Moscow, Respublika Publ., 1993. 431 p.

21. Bulgakov S.N. Khristianskii sotsializm. Spory o sud'bakh Rossii [Christian Socialism. Disputes the Fate Russia]. Novosibirsk, Nauka Publ., 1991. 350 p. 


\section{Информация об авторах}

Ерофеева Ирина Викторовна - Аоктор филологических наук, заведующая кафедрой журналистики и связей с общественностью, Забайкальский государственный университет, Россия, Чита, e-mail: irina-jour@yandex.ru

Муравьёв Алексей Валерьевич - магистр по направлению “ПеАагогическое образование", преподаватель Хулуньбуирского института, г. Хайлар (KHP), e-mail: alexey_muravioff@mail.ru

\section{有关作者的信息}

Erofeeva I.V. 一 语言博士，新闻学与公共关系教研室主任，后贝加尔国立大学，俄罗斯联邦， 赤塔。电子信箱: irina-jour@yandex.ru

Muravyov A.V. 一教育学硕士研究生，呼伦贝尔大学的讲师，海拉尔（中华人民共和国）。电子 信箱: alexey_muravioff@mail.ru

\section{Authors}

Irina V. Erofeeva - Doctor habil. in Philology, Head of Chair of Journalism and Public Relations, Transbaikal State University, Chita, Russia, e-mail: irina-jour@yandex.ru

Alexey V. Muravyov - Master in "Pedagogical Education", Lecturer of Hulunbuir Institute, Hailar, China, e-mail: alexey_muravioff@mail.ru

\section{Аия цитирования}

Ерофеева И.В. Культурная память России и Китая в ментальном ландшафте СМИ / И.В. Ерофеева, А.В. Муравьев // Российско-китайские исследования. - 2019. - Т. 3, № 4. - С. 53-65.

\section{For citation}

Erofeeva I.V., Muravyov A.V. Cultural Memory of Russia and China in Mental Landscape of Mass Media . Rossiisko-Kitaiskie Issledovaniya = Russian and Chinese Studies, 2019, vol. 3, no. 4, pp. 53-65. (In Russian). 